7-6-2018

\title{
Challenging the Estrangela / Serto Divide: Why the Standard Model of Syriac Scripts Just Doesn't Work
}

\author{
Kristina Bush \\ University of North Carolina at Chapel Hill \\ Michael Philip Penn \\ Stanford University \\ R. Jordan Crouser \\ jcrouser@smith.edu \\ Nicholas Howe \\ Smith College, nhowe@smith.edu \\ Shuangxia $\mathrm{Wu}$ \\ Brown University
}

Follow this and additional works at: https://scholarworks.smith.edu/csc_facpubs

Part of the Computer Sciences Commons

\section{Recommended Citation}

Kristina Bush, Michael Penn, R. Jordan Crouser, Nicholas Howe and Shwangxia Wu, "Challenging the Estrangela / Serto Divide: Why the Standard Model of Syriac Scripts Just Doesn't Work." Hugoye: Journal of Syriac Studies 21.1 (2018): 43-80.

This Article has been accepted for inclusion in Computer Science: Faculty Publications by an authorized administrator of Smith ScholarWorks. For more information, please contact scholarworks@smith.edu 


\title{
CHALLENGING THE ESTRANGELA / SERTO DIVIDE:
}

\author{
WHY THE STANDARD MODEL OF \\ SYRIAC SCRIPTS JUST DOESN'T WORK
}

\author{
KRISTINA BUSH \\ SCHOOL OF INFORMATION AND LIBRARY SCIENCE, UNC \\ CHAPEL HILL \\ MICHAEL PENN \\ RELIGIOUS STUDIES, STANFORD UNIVERSITY \\ R. JORDAN CROUSER \\ COMPUTER SCIENCE, SMith COLLEGE \\ Nicholas Howe \\ COMPuTER SCIENCE, SMith COLLEGE \\ SHUANGXIA WU \\ BROWN UNIVERSITY ${ }^{1}$
}

\begin{abstract}
1 The authors would like to thank Michael Davis, Ayda Kaplan, Adam McCollum, Ingred Nelson, Wesley Yu, and three anonymous reviewers for their extremely helpful feedback. So, too, this work would not have been possible without the generous financial support of the American Council of Learned Societies, the Andrew W. Mellon Foundation, Mount Holyoke College, and Stanford University. We also want to thank an amazing team of research assistants including: Hanna Baptist, Christine Barney, Minyue Dai, Alexandra Brennan, Rachyl Carey, Cass Fernandez-Dieguez, Kaylynn Crawford, Emma Dalton, Giovanna Diaz, Robin Graney, Elizabeth Knoll,
\end{abstract}




\begin{abstract}
As part of a larger digital paleography project, our team has assembled a database of tens of thousands of individual Syriac letters and letter data from 96\% of extant early Syriac manuscripts that have a secure composition date. Long term, such data can help scholars develop more accurate ways to classify Syriac scripts. In the present article we use this data to illustrate just how frequently the most common way of categorizing Syriac scripts as either Estrangela or Serto does not accurately convey the ways early scribes actually wrote. In addition to challenging this "Standard Model" of Syriac scripts, the project illustrates bow large data sets, digital analysis, and visual analytics can belp researchers address key philological and historical problems.
\end{abstract}

Ruben Duval's 1881 Traite Syriaque begins with a series of charts outlining the development of Syriac script. These charts divide the language into three scripts, a much later "Nestorian" script and-the focus of the present paper-two earlier scripts. According to Duval, the original Syriac script was Estrangela and, starting in the eighth century, there appeared a derived script that Duval termed "Jacobite" but is more commonly known as Serto. Duval was not the first scholar to divide early Syriac into these mutually exclusive script styles; similar divisions are extant among tenth-century Arabic writers and also appear in the thirteenth-century Syriac writings of Bar Hebreaus. ${ }^{2}$ This terminology was later adopted by most scholars of Syriac and, by the late nineteenth century, this

Gabrielle Lachtrup, Laura Larson, Audrey Lehrer, Sam Miller, Breanna Murphy, Bianca Ng, Paige "Gigi” Zeiler, Carmen Paul, Isabelle Pequignot, Caitlin Rajala, Siddhi Shah, Becca Shofar, Julia Spector, Sara Therrien, Renee Wah, Stephanie Xie, Alice Yang, and Kira Yates. Inquiries about this article should be directed to Michael Penn at mppenn@stanford.edu.

2 George Anton Kiraz, A Grammar of the Syriac Language. Volume 1. Orthography (Piscataway, NJ: Gorgias Press, 2012), 215. 
schema was so well known that even the Victorian novelist George Eliot referred to Estrangela in her notebooks. ${ }^{3}$

Since the nineteenth century, our knowledge of the Syriac language has advanced immensely. But, when it comes to our categories of Syriac script, these have remained essentially the same. Consider, for example, Figure 1. On the left is the Syriac section of the script chart Duval published in 1881. To the right appears a 2016 script chart found in the most recently published Syriac text book. ${ }^{4}$ In almost all details these are identical. They show three scripts, Estrangela, Serto (aka. Jacobite), and the much later East Syrian (aka. Nestorian). For the focus of this paper, Estrangela and Serto, there is little morphological variation between certain letters (e.g. zayn, nun). For a number of letters, however, there is substantial variation between the two scripts (i.e. olaph, dolath, he, waw, mim, rish, taw, and final lomahd). ${ }^{5}$ As both the 1881 and 2016 script charts suggest, what makes these categories so appealing is how easily one can differentiate them from each other. For those letters that show variance, an Estrangela document will

3 Jane Irwin, George Eliot's Daniel Deronda Notebooks (Cambridge: Cambridge University Press, 1996), 406, 438.

4 Steven C. Hallam, Basics of Classical Syriac: Complete Grammar, Workbook, and Lexicon (Grand Rapids: Zondervan, 2016).

${ }^{5}$ Final ayn could also be added to this list. But, because a final ayn appears so infrequently in Syriac, it was not feasible for us to identify a final ayn in every document. Our preliminary analysis suggests, however, that a scribe that uses an $\mathrm{E}$ final lomadh also uses an $\mathrm{E}$ final ayn and a scribe who uses an $\mathrm{S}$ final lomadh also uses an $\mathrm{S}$ final lomadh. The mim undergoes at least two substantial changes over time: 1) the earliest book hands usually have an open form of the mim in which they maintain a small opening on the baseline (just as they do a waw); 2) long after a closed form of the mim becomes popular, it further changes shape with a loop on the right and a left arm that meets the baseline making a v-shape on top. Because of our interest in earlier manuscripts, we have focused on the first of these changes and are defining an $\mathrm{E}$ mim as having an opening on the base line. There are also several letters, particularly gomal, teth, qoph, and shin that develop a substantially rounder form over time. But among securely dated manuscripts these more rounded forms do not clearly appear until the twelfth century and therefore are not the focus of this paper. 
only have Estrangela letter forms (what we will call E forms). For those letters that show variance, a Serto document will only have Serto letter forms (what we call S forms). The history of these scripts is often depicted as equally simple. Estrangela came first. Serto suddenly emerged in the eighth century as a more cursive form of Estrangela that eventually surpassed its parent in popularity.

Appearing in introductory Syriac text books, these tables were primarily intended for beginning students to use when they encountered printed text, not manuscripts. Indeed, these script charts work fairly well for printed text and even for most manuscripts written after the thirteenth century. In recent years, several scholars have noted the limitations of applying such a schema to early manuscripts. Nevertheless, no alternative model has gained general acceptance. As a result, what appears in introductory text books is also commonly used for early manuscripts. In other words, the text book model has become essentially the Standard Model. The resulting schema of clearly and exclusively defined Estrangela and Serto remains the main paradigm for classifying Syriac script. It is found, with very little deviation, not only in almost every modern text book of Syriac, but also in most manuscript catalogs, in the only substantial paleographic resource in the field, and even in that most important arbiter of world knowledge, Wikipedia. ${ }^{6}$ The

${ }^{6}$ Similar charts can be found in most every text book of Syriac. For examples, see J.F. Coakley, Robinson's Paradigms and Exercises in Syriac Grammar, 6th Edition (Oxford: Oxford University Press, 2013), 3, 142; George Anton Kiraz, The New Syriac Primer (Piscataway, NJ: Gorgias Press, 2007), 232-233; Takamitsu Muraoka, Classical Syriac: A Basic Grammar with a Chrestomathy (Wiesbaden: Herrassowitz, 1997), 3; Wheeler M. Thackston, Introduction to Syriac (Bethesda: IBEX Publishers, 1999), xvii-xviii. So, too, William Henry Paine Hatch, An Album of Dated Syriac Manuscripts (Boston: The American Academy of Arts and Sciences, 1946), the only published album of securely dated Syriac manuscripts is organized around the categories of Estrangela and Serto. Hatch's Album begins with the oldest dated manuscript that he considered to be in Estrangela (British Library Additional 12,150, securely dated to $411 \mathrm{CE}$ ) and once he gets to the latest Estrangela manuscript in his Album, (Berlin Syriac 20, securely dated to 
problem with an all-purpose Standard Model derived from introductory text book script charts is clearly not obscurity. The problem with such a Standard Model is that when one applies it to early Syriac manuscripts, in almost every aspect it is simply dead wrong.

As can be seen in Figures 2 and 3, in addition to its general success when applied to modern printed text, the Standard Model does indeed work well for some manuscripts. Figure 2 follows a page from British Library Additional 14,428 (securely dated to $500 \mathrm{CE}$ ) which matches the text book definition of Estrangela. The olaph, dolath, he, waw, mim, rish, taw, and final lomadh match the text book charts of Estrangela forms, that is they are what we call the E forms. Figure 3 shows a page from British Library Additional 17,194, f. 20b (securely dated to $886 \mathrm{CE}$ ) which matches the text book charts of Serto. All the variable letters are in what we are calling the $S$ forms and match what text books attribute to Serto. In other words, the text book script charts originally designed for printed texts also work for these manuscripts. In such cases, it remains unproblematic to use the text book chart as an all-purpose Standard Model. But anyone who looks at even a small number of early Syriac manuscripts must confront many unlike those in Figures 2 and 3. One frequently encounters cases where the text book script charts do not at all jive with what is being read. Such manuscripts illustrate the problem with misapplying script charts initially designed for printed text as an all-purpose Standard Model of Syriac script.

We are far from the first to notice this. Those who work directly with Syriac manuscripts quickly become aware of this model's shortcomings. So, too, several recent articles have

1567/1568 CE), Hatch begins again with what he considers to be the earliest manuscript in Serto (Harvard Syriac 176, that Hatch erroneously dates to $731 / 732 \mathrm{CE}$ ). Most manuscript catalogs use similar nomenclature (for a comprehensive list of catalogs see http://syri.ac/manuscripts). This clear divide between Estrangela and Serto can even be found in the Wikipedia article "Syriac Alphabet" (https://en.wikipedia.org /wiki/Syriac_alphabet). 
noted various inadequacies of this Standard Model, as has the catalog of those manuscripts remaining in Deir al-Surian and, in greatest detail, a yet-to-be published dissertation by Ayda Kaplan. ${ }^{7}$ Nevertheless, such critiques—whether coming from one's own experience or from these publications-stem from a fairly small sampling of Syriac manuscripts. As a result, few appreciate just how often the Standard Model fails, especially when applied to early Syriac manuscripts, and previous critics have not yet affected the way most categorize Syriac script.

As part of a much larger project using recent advances in the computerized analysis of handwriting to better study Syriac manuscripts, our digital humanities team has assembled the world's largest collection of Syriac letter forms. This database of more than 60,000 individual letter images allows one to better identify the inadequacies of the Standard Model for classifying Syriac script. Long term, this collection of letter images can assist scholars in developing more accurate script categories. In terms of this article, however, our goal is simply to document more thoroughly and quantify more clearly the limitations of the most common way early Syriac manuscripts are classified. We employ two distinct datasets to do this.

The first dataset comes from Syriac manuscripts that include a composition date, usually found in a production

${ }^{7}$ E.g. Ayda Kaplan, "The Shape of the Letters and the Dynamics of Composition in Syriac Manuscripts (fifth to Tenth Century)," in Ruling the Script in the Middle Ages: Formal Aspects of Written Communication Books, Charters, and Inscriptions), ed. D. Stutzmann S. Barret, and G. Vogeler (Turnhout: Brepols, 2016), 379-398; Ayda Kaplan, "La paléographie syriaque: proposition d'une méthode d'expertise," in Manuscripta Syriaca: Des sources de première main, ed. Fraçoise Briquel Chatonnet and Muriel Debié (Paris: Geuthner, 2015), 307-319; Andrew Palmer, "The Syriac LetterForms of Tūr Abdīn and Environs," Oriens Christianus 73 (1989): 68-89. Sebastian Brock and Lucas Van Rompay, Catalogue of the Syriac Manuscripts and Fragments in the Library of Deir-al Surian, $W$ adi Al-Natrun (Egypt) (Leuven: Peeters, 2014), XXI-XXII. Ayda Kaplan, "Syriac Paleography: The Development of a Method of Expertise on the Basis of the Syriac Manuscripts of the British Library (Vth-Xth c.)" (PhD, Université Catholique de Louvain, 2008). 
colophon. Currently, our project has digital image from 156 of the 183 extant Syriac manuscripts securely dated to before the twelfth century, (that is $85 \%$ ). ${ }^{8}$ As shown in Figure 4, for each of these manuscripts, research assistants used a customdesigned Java interface to identify for the computer six to ten examples of each Syriac letter form. The letter selections were proofed by a Syriac scholar, given appropriate metadata, binarized, and digitally trimmed to remove any stray marks. The computer then helped scholars visualize these tens of thousands of letter images through the creation of automatic, customizable script charts. The charted letter forms we used for this paper's analysis were also cross-checked with the original manuscript images to ensure accuracy. There was, however, a smaller number of securely dated manuscripts for which we were unable to obtain digital images but that did appear in previously published images. For example, in 2006 the Cincinnati Historical Society sold the manuscript known as Codex Syriacus Secundus (dated 882 CE) to a private collector. Although we were unsuccessful in obtaining images directly from the collector, we were able to consult color pictures in

${ }^{8}$ For an invaluable check list of early, securely dated Syriac manuscripts see Sebastian Brock, "A Tentative Checklist of Dated Syriac Manuscripts up to 1300," Hugoye: Journal of Syriac Studies 15,1 (2012): 21-48. Our own figures are based on a slight modification of Brock's list and include the following emendations: Added: Saint Marks 7; Sinai Syriac M51N. Because in CPA script removed Vatican Syriac 19. In an abundance of caution, removed those manuscripts that had either a pre- or circa date (i.e. British Library Additional 14,526; British Library Additional 14,567; British Library Additional 14,605; Damascus Patriarch 12/25) or a missing number in the colophon (i.e. British Library Additional 7158; Dolabani 145). Removed British Library Additional 14,645 as the colophon date refers to when the text was translated not when it was produced. Removed manuscripts that others have identified as having an incorrect date in their colophon (i.e. Chester Beatty 701; Harvard Syriac 176; Paris Syriac 169). Removed St. Petersburg N/S 24 as the folio is too damaged to ensure that the date that appears without much context in the colophon is a composition date. Removed Mingana Syriac $106 \mathrm{G}$ as the stray leaves Mingana identified are no longer locatable in the University of Birmingham collection. 
the Christie's Auction House catalog. ${ }^{9}$ Similar cases allowed us to examine published images of an additional 19 early dated manuscripts. All together this yielded a dataset of 175 manuscripts or $96 \%$ of the known extant Syriac manuscripts securely dated to before the twelfth century. The resulting sample contains the vast majority of early dated examples now distributed among 16 modern collections and forms the core material for our analysis of Syriac script. ${ }^{10}$

A second dataset supplements this collection of securely dated manuscripts. We also obtained images from an additional 593 manuscripts in the British Library collection that the nineteenth-century cataloger William Wright estimated were written between the fifth and eleventh centuries. These manuscripts do not contain a securely dated colophon and there is not yet a way to confirm the accuracy of Wright's estimates. Therefore, we do not use these manuscripts to establish a chronology of Syriac script development. Nevertheless, these undated manuscripts do allow one to use the world's largest holding of early Syriac manuscripts as a case study to further quantify how often the Standard Model fails to accurately describe Syriac manuscript script.

Combined, this forms a collection of 768 manuscripts whose analysis reveals at least four systemic flaws in using the Standard Model for classifying Syriac scripts in early manuscripts: 1) A given scribe often used both $\mathrm{E}$ and $\mathrm{S}$ forms of the very same letter in the very same manuscript; 2) A given scribe often used $\mathrm{E}$ forms of some letters and $\mathrm{S}$ forms of other letters in the very same manuscript; 3) Several S letters first appeared long before the eighth century; 4) Even a survey of a small number of Syriac specialists shows how frequently they

9 The History of the Book: The Cornelius J. Hauck Collection of the Cincinnati Museum Center, Tuesday, 27 June, 2006, Wednesday, 28 June, 2006 (New York, N.Y. : Christie's, 2006), 73-75.

10 These sample sets, of course, reflect the larger biases of what survives. For example, most extant early Syriac manuscripts were written by Miaphysites and many were obtained from just a few key monasteries. 
disagree on how to classify actual manuscripts using the prevailing nomenclature. Although previous scholars have alluded to a number of these issues, we hope that our more systematic and quantitative analysis will help convince the Syriac community of the necessity for a new classification system for manuscript script.

\section{Problem 1: A Given Scribe Often Used both $\mathrm{E}$ and $\mathrm{S}$ Forms of the Same Letter within a Single Manuscript}

According to the Standard Model, any given document should use either an E or an S form of a given letter. No text book has a chart of Estrangela that includes examples of $\mathrm{S}$ forms of an olaph, dolath, he, waw, mim, rish, taw, or final lomadh. No text book has a chart of Serto that includes an E form of an olaph, dolath, he, waw, mim, rish, taw, or final lomadh. According to these tables and their descriptions, if one finds a document using an E olaph, every other olaph the document used would also take an $\mathrm{E}$ form. If a document uses an $\mathrm{S}$ rish, every other rish in that document should also be an $\mathrm{S}$ form.

The first challenge to applying this Standard Model to early manuscripts is that in many cases a single manuscript hand will contain both the $\mathrm{E}$ and $\mathrm{S}$ forms of the very same letter, usually on the very same page, often in the very same word. For example, Figure 5 shows a page from British Library Additional 14,548 securely dated to 790 CE. Upon first glance, this manuscript appears to match the Standard Model of Serto. It contains S forms of olaph, dolath, he, waw, mim, rish, and taw. However, upon a closer look, it is clear that the E form of olaph is also present.

As Figure 6 shows, the scribe of British Library Additional 14,548 was far from alone in using both $\mathrm{E}$ and $\mathrm{S}$ forms of olaph. Here securely dated manuscripts are represented chronologically from left to right. If more than one scribe contributed to a manuscript, the chart treats each hand independently. For each manuscript hand, a dot shows 
whether the scribe used only $\mathrm{E}$ forms of the olaph, S forms of the olaph, or both E and S forms of the olaph. ${ }^{11}$ Every dot in the "both" row defies a cardinal rule of the Standard Model for Syriac script.

These are not occasional occurrences. No less than 53 of the 175 securely dated manuscript hands we examined display at least one Syriac letter in both its $\mathrm{E}$ and $\mathrm{S}$ form. This becomes especially prevalent between the ninth and eleventh centuries, when $38 \%$ of securely dated manuscripts show such overlap. These violations of the Standard Model are not, however, just confined to these later centuries. For example, as is well known, even the earliest securely dated Syriac manuscript, British Library Additional 12,150 (411 CE), has both E and S dolaths and rishs. Such appearance of both $\mathrm{E}$ and $\mathrm{S}$ letter forms cannot be explained by a change in scribes; the letter forms appear to come from a singular hand, are found on the same page, and often two forms of the same letter occur within the very same word. In addition to these securely dated examples, our team's collection of 593 British Library manuscripts that Wright estimated as having been written in the fifth through tenth century includes no less than 169 further cases of a scribe using both $\mathrm{E}$ and $\mathrm{S}$ forms of the same letter. Most often a scribe will use both the $\mathrm{E}$ and $\mathrm{S}$ forms of an olaph (often as an aid for line justification), but both forms of dolath, he, rish, and taw also appear in some manuscript hands.

A key component of text book script charts and their application as a Standard Model is that Estrangela and Serto are separate categories that do not overlap with each other. Yet for almost every variable letter, one finds multiple cases of a single hand employing both an $\mathrm{E}$ and an $\mathrm{S}$ form. The numerous examples of scribes using $E$ and $S$ forms of the same letter within a given manuscript, often even within a given word, defies the logic behind two exclusive categories of early

11 An interactive form of this chart, along with that of other letters, can be found at https://tinyurl.com/EstrangelaSerto. 
Syriac scripts. Even if such a system might work for modern printed text or for relatively late manuscripts, it certainly does not for earlier manuscripts.

\section{Problem 2: A Given Scribe Often Used E Forms of Some Letters and S Forms of Other Letters within a Single Manuscript}

Text book script charts suggest that a given document should have either $\mathrm{E}$ forms of all the letters or $\mathrm{S}$ forms of all the letters. That is, if the document has an $\mathrm{E}$ olaph, for example, so too its dolath, he, waw, mim, rish, taw, and final lomadh should all be $\mathrm{E}$ forms. Or, if a document has an $\mathrm{S}$ form of olaph, so too its dolath, he, waw, mim, rish, taw, and final lomahd should all be $\mathrm{S}$ forms. But this does not work well for early manuscripts. Here $\mathrm{E}$ forms of certain letters and $\mathrm{S}$ forms of other letters often coexist in the same manuscript.

These mixed-form manuscripts are far from uncommon. Consider, for example, British Library Additional 14,579 in Figure 7, securely dated to $913 \mathrm{CE}$. This manuscript contains E olaph, taw, and final lomadh mixed with $\mathrm{S}$ dolath, he, waw, mim, and rish. Based on the Standard Model, this manuscript should not exist. The importance of manuscripts, such as British Library Additional 14,579, is that they challenge the application of text book script charts to early manuscripts.

These are not infrequent challenges and their prevalence is illustrated by Figures $8-12$. This set of visualizations will take a moment to get used to. On the first (Figure 8) a single securely dated manuscript, in this case Deir al-Surian 10, is shown as a line. ${ }^{12}$ The plot's horizontal axis consists of the Syriac letter

12 For those reading the on-line version of this article, the line's color represents its date, ranging in a spectrum from red for the earliest manuscripts in the sample to blue for the latest. In this case, dated $510 \mathrm{CE}$, Deir al-Surian 10 is in red. 
forms of dolath, he, waw, mim, rish, taw, and final lomadh. ${ }^{13}$ The vertical axis has E letter forms at the top, $\mathrm{S}$ letter forms at the bottom, and cases where a manuscript uses both $\mathrm{E}$ and $\mathrm{S}$ forms of the same letter in the middle. As for Deir al-Surian 10, it follows the text book definition of Estrangela and has $\mathrm{E}$ forms of all variable letters. Thus it is a straight line at the top of the chart.

Figure 9 is a hypothetical example using the same layout but now with almost all manuscripts securely dated to before the twelfth century. It shows what such a chart would look like if manuscripts consistently followed the Standard Model. ${ }^{14}$ All of the chart's lines would be perfectly horizontal as any manuscript containing a given Syriac letter in an E form would have all other letters in an $\mathrm{E}$ form and any manuscript containing a given Syriac letter in an $\mathrm{S}$ form would have all other letters in an S form.

In contrast to the hypothetical chart in Figure 9, Figure 10 displays actual letter data from 175 manuscripts securely dated to before the $1100 \mathrm{~s} .{ }^{15}$ Each line that crosses through the center of this chart represents a manuscript that disproves an insistence that Syriac manuscripts use either exclusively E forms or exclusively S forms. As Figure 10 illustrates, such violations of the Standard Model's central premise are not rare. In fact, $30 \%$ of all securely early dated manuscripts contain

${ }^{13}$ In these visualizations we combine waw and mim as in the main text of all manuscripts we examined a scribe used the same form, either E or S, for both of these letters.

${ }^{14}$ For those reading the on-line version of this article, the line's color represents its date, ranging in a spectrum from red for the earliest manuscripts in the sample to blue for the latest. In this case, according to the Standard Model, Estrangela developed first, so all reddish lines would be on the top. Because, according to the Standard Model, Serto did not develop until the eighth century only bluish lines would be on the bottom. But, because some later scribes continued to use Estrangela, some bluish lines could also be found on the top.

15 An interactive form of this chart allowing one to plot out any combination of securely dated manuscripts in our database can be found at https://tinyurl.com/EstrangelaSerto. 
both E forms of some letters and S forms of others. Although not as useful as securely dated manuscripts for tracing the chronological development of Syriac script, our dataset of 593 manuscripts that Wright estimated were written before the twelfth century also illustrates the prevalence of mixed-script manuscripts. As can be seen in Figure 11, 220 manuscripts, that is $38 \%$ of the total sample, contain E forms of some letters and $\mathrm{S}$ forms of others in the same manuscript. More detailed analysis of securely dated examples indicates that this problem only compounded over time. In the fifth and sixth centuries, only seven securely dated manuscripts have mixed $\mathrm{E}$ and $\mathrm{S}$ forms, constituting 14\% of the manuscripts from that period. The number of mixed-script manuscripts vastly increases in the next two centuries constituting $22 \%$ of seventh- and eighth-century manuscripts. Figure 12, limits itself to the ninth and tenth centuries and shows that $44 \%$ of all securely dated manuscripts from those years have $\mathrm{E}$ forms of some letters and $S$ forms of others.

\section{Problem 3: Letters Developed S Forms at Different Times}

The alleged eighth-century birth of Serto becomes even more problematic when one discovers that $\mathrm{S}$ forms developed at different times, often well before the eighth century. British Library Additional 12,150 again substantiates this point with the appearance of the $\mathrm{S}$ forms of dolath and rish in $411 \mathrm{CE}$. Dolath and rish are the first $\mathrm{S}$ forms found in the main text of a manuscript and of the securely dated manuscripts produced before the eighth-century, $11 \%$ contain $\mathrm{S}$ forms of dolath, rish, or in most cases both.

He, waw, and mim were the next letters to appear in their S form among securely dated manuscripts. Although earlier securely dated manuscripts occasionally employ a closed waw and mim, the first to consistently do so is British Library Additional 17,110 securely dated to 599/600 CE. ${ }^{16}$ As Figure 13

${ }^{16} \mathrm{~S}$ forms of he, waw, and mim also appear in Vatican Syriac. 137. Due to its colophon, the eighteenth-century catalogers Joseph Simone Assemani 
illustrates, British Library Additional 17,110 uses the S forms of dolath, rish, he, waw, and mim but $\mathrm{E}$ forms of olaph and taw. An $\mathrm{S}$ form he is found in six of the 61 manuscripts securely dated to before the eighth century, that is in 10\% of all securely dated manuscripts produced before the supposed development of the Serto script. Similarly, $8 \%$ of all securely dated manuscripts made prior to the 700 s used the $S$ form of waw and mim.

In total, $16 \%$ of securely dated manuscripts produced before $700 \mathrm{CE}$ contain at least one S form of the letters dolath, he, waw, mim, and rish. In contrast the $S$ forms of olaph, taw, and final lomadh in the main text of a securely dated manuscript do not occur until significantly later, first appearing in Berlin Syriac 26 dated to 740 CE., two centuries after the first appearance of the $\mathrm{S}$ forms of he, waw, and mim. The $\mathrm{S}$ olaph, taw, and final lomadh do not, however, become common until much later when $59 \%$ of all securely dated manuscripts produced in the ninth century and tenth centuries use the $\mathrm{S}$ form olaph. The taw shows a similar pattern, with $51 \%$ of all securely dated ninth- and tenth-century manuscripts using the $\mathrm{S}$ form.

The Standard Model obscures a much more complicated history of Syriac script. Among the main text of securely dated manuscripts, there are four distinct points in which different $S$ letter forms first appear: $411 \mathrm{CE}$ (dolath, rish), 599/600 CE (he, waw, and mim), $740 \mathrm{CE}$ (olaph) and $790 \mathrm{CE}$ (taw, final lomadh). Rather than suddenly emerging in the eighth century, the letter forms that make up the Standard Model's definition of Serto all appear at different times and the majority first appear long before the $700 \mathrm{~s}$.

and Stephanus Evodius Assemani dated Vatican Syriac 137 to 564 CE. Unfortunately, the year is no longer legible in the manuscript and cannot be verified. If the Assemanis were overly optimistic about their ability to ascertain a date, then 599/600 would remain the earliest secure date for the display this pattern. If the Assemanis were correct, these forms first appeared a few decades earlier. 
Even this story, however, has to be substantially qualified. For up to now we have been dealing exclusively with the history of Syriac book hand which was used to copy the main text of a manuscript. In 2000, John Healey and, in 2005, Fraçoise Briquel-Chatonnet noted that many of the letter forms associated with Serto did not first appear in the main text of Syriac manuscripts. Rather, their earliest attestation can be seen in Syriac mosaics, a collection of three third-century Syriac documentary papyri, and five examples of securely dated manuscripts in which an early scribe wrote the main text only with $\mathrm{E}$ forms, but then wrote the manuscript's colophon in a more current hand using one or more $\mathrm{S}$ forms. ${ }^{17}$ From this data, Healey and Briquel-Chatonnet concluded that Serto was not necessarily a later script than Estrangela. Instead, from the very beginning, Syriac had multiple script styles. A more monumental script, what we generally call Estrangela, was used for both inscriptions and as a book hand. At the same time, a more everyday script was often used in documentary sources, in some mosaics and, in manuscripts, during slightly more informal situations such as writing a colophon.

Detailed in a forthcoming article, our team has expanded the evidence cited by Healey and Briquel-Chatonnet to include an additional 36 notes containing $\mathrm{S}$ forms that are securely dated to before the eighth century. ${ }^{18}$ With the exception of the $S$ forms of dolath and rish found in British Library 12,150, the earliest securely dated witness to all other variable letters appears outside of the manuscript's main text.

17 John F. Healey, "The Early History of the Syriac Script a Reassessment," Journal of Semitic Studies 14,1 (2000): 55-67; Françoise Briquel-Chatonnet, "Some Reflections about the Origin of the Serto Script," The Harp: A Review of Syriac and Oriental Studies 18 (2005): 173-177. Much of Healey's article was previewed a year earlier in Hans J.W. Drijvers and John F. Healey, The Old Syriac Inscriptions of Edessa and Osrhoene: Texts, Translations and Commentary (Leiden: Brill, 1999), 1-19.

18 Michael Penn and Jordan Crouser, "Serto Before Serto: Reexamining the Earliest Development of Syriac Script." 
This points to a more nuanced development of Syriac script. In manuscripts written between the fifth and seventh centuries, most $\mathrm{S}$ forms first appear in examples of a current hand often preserved in scribal colophons and other notes. Initially, however, there was not a unified style for this current hand; various letter forms first appear among surviving colophons and notes at different times. Some of these letter forms (for example a mim written in the shape of a reversed epsilon) never move to the main text of Syriac manuscripts. But others, what we call the $S$ letters, later scribes adopted into a Syriac book hand albeit they adopted different letters at different times and in different combinations. In most cases this movement of an S form previously used only for a current hand into a book hand took place well before the 700s. Such a narrative differs substantially from the Standard Model depicted in text book script charts or in the often repeated claim that Serto first appeared in the eighth century.

\section{Problem 4: Modern Scholars Cannot Agree on How to Classify Manuscripts}

Independent of its empirical accuracy, the Standard Model of Syriac script classification has a final, fatal flaw. If one looks at published script charts and text book descriptions, in theory it seems extremely clear cut what is Estrangela and what is Serto. But due to the difficulties of conforming the simplicity of this schema with the complexities of actual manuscript data, in practice scholars vary sharply in how they actually classify early manuscripts. To test the prevalence of such confusion, members of our team devised a survey of 33 images from manuscript securely dated to before the twelfth century. We then ordered these randomly and sent them to five well-known specialists in Syriac Studies. Eight of the images came from manuscripts that contained only E letter forms. Six came from manuscripts that contained only $\mathrm{S}$ forms of variable letters. The remaining 21 images came from manuscripts that illustrated some of the problems with the Standard Model, having either the $\mathrm{E}$ and $\mathrm{S}$ form of a particular letter, or a 
mixture of $\mathrm{E}$ forms of certain letters and $\mathrm{S}$ forms of other letters. For each manuscript image, the scholars were asked two questions: 1) "If you could only choose between Serto and Estrangela to define this manuscript, which would you choose? a) Serto or b) Estrangela"; and 2) "If a third category, Medial, is introduced, how do you now define the manuscript? a) Serto, b) Estrangela, c) Medial."

Figure 14 shows the results for the manuscripts that had either all $\mathrm{E}$ or all $\mathrm{S}$ letter forms. We initially considered these to be control images given their strong adherence to the Standard Model and expected consensus. In the case of the eight manuscripts with only E letter forms, all five scholars indeed did consistently categorize them as Estrangela. But quite unexpectedly, among the six manuscripts that had all S letters there was disagreement. One scholar consistently preferred to characterize all of these manuscripts with the intermediate category of Medial. Two other scholars, dissented from the majority in three additional cases.

As can be seen in Figure 15, the results were much more divergent when it came to manuscripts with a combination of $\mathrm{E}$ and $\mathrm{S}$ forms. The bolded font represents minority opinions for each manuscript. Of these nineteen manuscripts, scholars could agree on their complete classification for only one of them. For the other eighteen, there was at least one out of the five scholars who dissented and, for most, there was a 3-2 split. This divide became especially pronounced when scholars were given the option of a third, intermediate category. Yet for seven of these manuscripts, there was disagreement over even the initial designation as either Estrangela or Serto.

There were few identifiable patterns for how the scholars classified manuscripts that contained both $\mathrm{E}$ and $\mathrm{S}$ letter forms; each had their own manner of identifying the script used. One scholar, for example, tended to categorize mixed E and $\mathrm{S}$ scripts as Estrangela and then Medial, while another often identified these manuscripts only as Estrangela. A closer look at the data reveals that the letter which most influenced these scholars' decision on characterizing a manuscript as Serto 
was the presence of an S olaph. If a manuscript had an S olaph, $76 \%$ of the responses initially categorized it as Serto. Among the approximately one quarter of responses that dissented, two thirds of these switched from Estrangela to Medial when given the opportunity. So, at the end of the second question, $56 \%$ of the mixed $\mathrm{E}$ and $\mathrm{S}$ form manuscripts that had an $\mathrm{S}$ form olaph were identified as Medial, $36 \%$ as Serto, and only $8 \%$ as Estrangela irrespective of the other letters. The greatest influence on these scholars characterizing a manuscript with mixed $\mathrm{E}$ and $\mathrm{S}$ forms as Estrangela was the combination of an $\mathrm{E}$ olaph and an E taw. Of the 14 manuscripts that contained five $S$ letter forms but had an E olaph and taw, 12 manuscripts were unanimously initially classified as Estrangela despite most of their variable letters having an $\mathrm{S}$ form. For the other two manuscripts with $\mathrm{E}$ olaph and taw but $\mathrm{S}$ forms of the other variable letters, four scholars initially classified them as Estrangela and one scholar as Serto.

Although from a small survey, the results are still rather shocking. Expanding the number of respondents would likely show even less consensus. Given the disconnect between the reigning model of Syriac script originally developed for printed text and actual script usage in early manuscripts, every scholar has essentially developed their own way to classify the manuscripts that they are reading. Most do this without recourse to any larger sample or to quantitative data resulting in a lack of scholarly consensus. If this small survey turns out to be even somewhat representative, it also suggests that when scholars classify the script of an early manuscript, they often do so by over relying on one or two letter forms at the expense of the majority of others.

The problem lies not in text book script charts, as long as one uses them only for printed texts or for relatively late manuscripts. But in the absence of a well-articulated classification schema for how Syriac script actually appears in early manuscripts, many have misapplied text book script 
charts to a medium for which they were not designed. As a result, a text book model has often become the Standard Model, an all-purpose schema that simply does not work for early materials. For early Syriac scribes often used E and S forms of one letter interchangeably. They often used $\mathrm{E}$ forms of some letters and S forms of others. In book hands, the various $S$ letter forms first appear at different times usually long before the purported eighth-century birth of Serto and they most often appear in the current hand of manuscript notes even earlier. Researchers cannot agree on script identifications of early manuscripts, not even those manuscripts that generally fit this Standard Model.

Scholars such as Sebastian Brock, Ayda Kaplan, Andrew Palmer, and Lucas Van Rompay have proposed various alternatives to simply an Estrangela or Serto classification of early Syriac script. ${ }^{19}$ Sometimes these models add additional qualifications such as "early" versus "late" Serto. Other times, an expansion of the Standard Model simply includes a third class such as "Medial" alongside Estrangela and Serto. In the case of Kaplan's schema, there is a wholesale abandonment of the terms Estrangela and Serto and their replacement by the more nuanced categories of "monumental," "monumental semi-cursive," "cursive semi-monumental," and "formal cursive."

This article does not attempt to adjudicate between these approaches nor to present a new nomenclature. Rather, our goal has been simply to illustrate how desperately the Standard Model of Syriac script classification needs much more than just a little tweaking or a minor repair whenever one categorizes early Syriac manuscripts. We hope this will assist other scholars to develop a terminology and a history of Syriac script that

19 Rompay, Syriac Manuscripts of Deir-al Surian, XXI-XXII; Palmer, "Syriac Letter Forms," 68-89; Kaplan, "Shape of the Letters," 379-398; Kaplan, "La paléographie syriaque," 307-319; Kaplan, "Syriac Paleography: The Development of a Method of Expertise on the Basis of the Syriac Manuscripts of the British Library (Vth-Xth c.)", 
much more accurately describe the ways early Syriac scribes actually wrote. ${ }^{20}$

20 To further assist in this, we are in the process of making our letter data set publically available. In about a year, scholars should be able to create on-line customized, automatically generated charts of both the main script of most early securely dated manuscripts as well as the script of early securely dated notes. So, too, full page images from most of these sources should be available. The interfaces will be linked to the two main on-line resources for Syriac studies, syriac.org and syri.ac and announced on the Hugoye list-serve. 


\section{BIBLIOGRAPHY}

. The History of the Book: The Cornelius J. Hauck Collection of the Cincinnati Museum Center, Tuesday, 27 June, 2006, Wednesday, 28 June, 2006 New York, N.Y. : Christie's, 2006.

Briquel-Chatonnet, Françoise. "Some Reflections about the Origin of the Serto Script." The Harp: A Review of Syriac and Oriental Studies 18 (2005): 173-177.

Brock, Sebastian. "A Tentative Checklist of Dated Syriac Manuscripts up to 1300." Hugoye: Journal of Syriac Studies 15,1 (2012): 21-48.

Coakley, J.F. Robinson's Paradigms and Exercises in Syriac Grammar, 6th Edition Oxford: Oxford University Press, 2013.

Drijvers, Hans J.W. and John F. Healey. The Old Syriac Inscriptions of Edessa and Osrhoene: Texts, Translations and Commentary Leiden: Brill, 1999.

Hallam, Steven C. Basics of Classical Syriac: Complete Grammar, Workbook, and Lexicon Grand Rapids: Zondervan, 2016.

Hatch, William Henry Paine. An Album of Dated Syriac Manuscripts Boston: The American Academy of Arts and Sciences, 1946.

Healey, John F. "The Early History of the Syriac Script a Reassessment." Journal of Semitic Studies 14,1 (2000): 5567.

Irwin, Jane. George Eliot's Daniel Deronda Notebooks Cambridge: Cambridge University Press, 1996. 
Kaplan, Ayda. "Syriac Paleography: The Development of a Method of Expertise on the Basis of the Syriac Manuscripts of the British Library (Vth-Xth c.)." PhD, Université Catholique de Louvain, 2008.

Kaplan, Ayda. "La paléographie syriaque: proposition d'une méthode d'expertise." In Manuscripta Syriaca: Des sources de première main, edited by Fraçoise Briquel Chatonnet and Muriel Debié, 307-319. Paris: Geuthner, 2015.

Kaplan, Ayda. "The Shape of the Letters and the Dynamics of Composition in Syriac Manuscripts (fifth to Tenth Century)." In Ruling the Script in the Middle Ages: Formal Aspects of Written Communication Books, Charters, and Inscriptions), edited by D. Stutzmann S. Barret, and G. Vogeler, 379-398. Turnhout: Brepols, 2016.

Kiraz, George Anton. The New Syriac Primer Piscataway, NJ: Gorgias Press, 2007.

Kiraz, George Anton. A Grammar of the Syriac Language. Volume 1. Orthography Piscataway, NJ: Gorgias Press, 2012.

Muraoka, Takamitsu. Classical Syriac: A Basic Grammar with a Chrestomathy Wiesbaden: Herrassowitz, 1997.

Palmer, Andrew. "The Syriac Letter-Forms of Tūr Abdīn and Environs." Oriens Christianus 73 (1989): 68-89.

Rompay, Sebastian Brock and Lucas Van. Catalogue of the Syriac Manuscripts and Fragments in the Library of Deir-al Surian, Wadi Al-Natrun (Egypt) Leuven: Peeters, 2014.

Thackston, Wheeler M. Introduction to Syriac Bethesda: IBEX Publishers, 1999. 


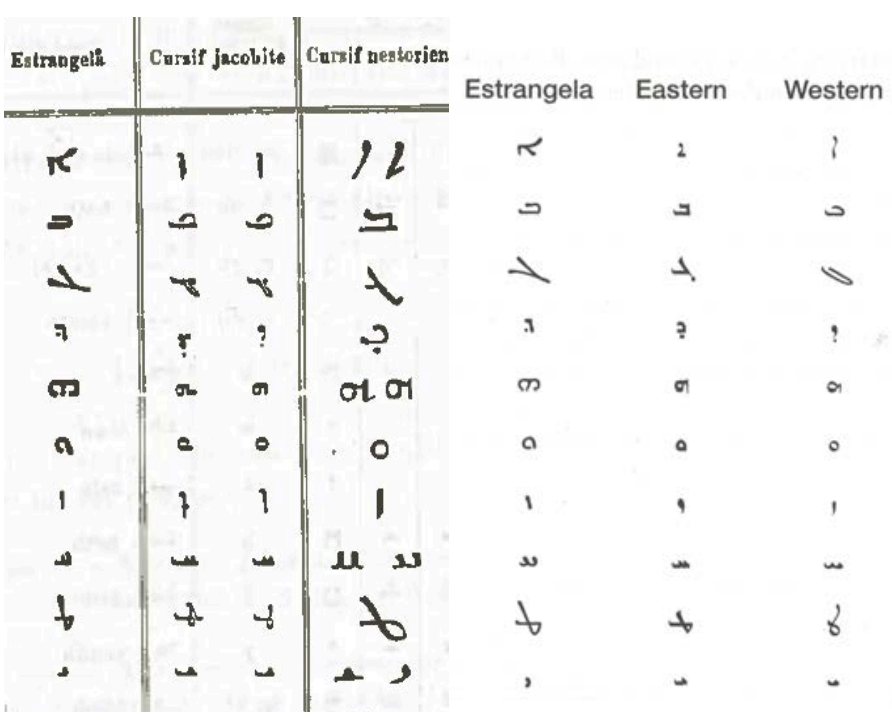

Figure 1. Typical Script Charts of Syriac. On the left appears the script chart from Ruben Duval's Traite Syriaque (1881) that divides Syriac into three exclusive scripts: later "Nestorian," and the two earlier scripts of Estrangela and Serto (what Duval calls "Jacobite"). On the right is the script chart from Steven Hallam's Basic Classical Syriac (2016), that uses the terms Estrangela, Eastern (instead of Duval's "Nestorian"), and Western (instead of Duval's "Jacobite" or the more common "Serto"). Despite the 135-year difference between when these script charts were published and their slightly different terminology, their categorization of Syriac script remain essentially the same. Almost all twentieth- and twenty-first-century Syriac script charts are virtually identical to these two. The second chart is taken from Basics of Classical Syriac by Steven C. Hallam. C) 2016 by Seven C. Hallam. Used by permission of Zondervan. www.zondervan.com. 


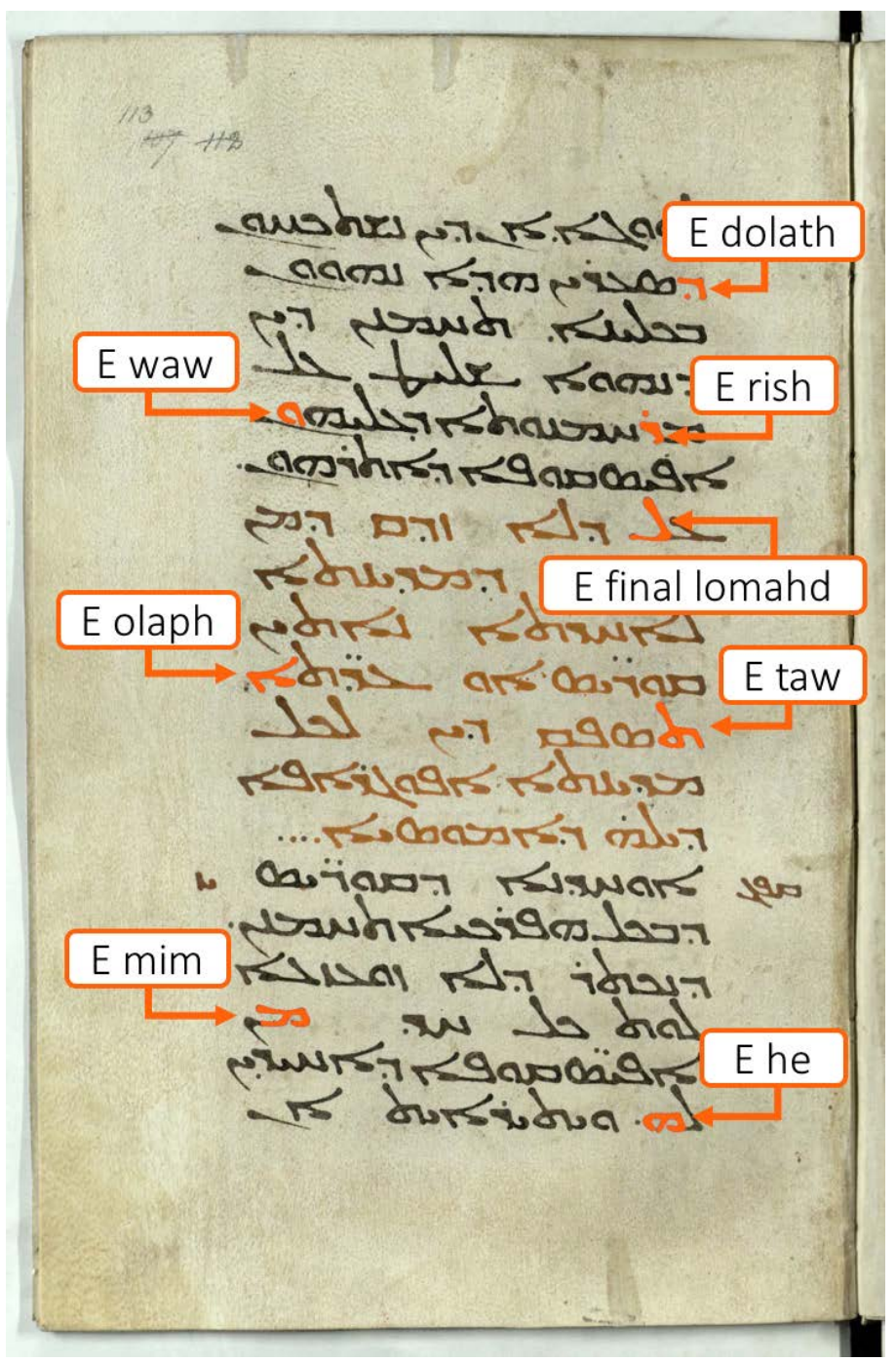

Figure 2. British Library Additional 14,528, f. 113a. Securely dated to $500 \mathrm{CE}$, this manuscript matches the Standard Model of an Estrangela manuscript. All its variable letters (olaph, dolath, he, waw, mim, rish, taw, and final lomadh) are in the forms text books attribute to Estrangela and that we are calling E forms. (C) British Library Board: BL. Add. 14,528. 


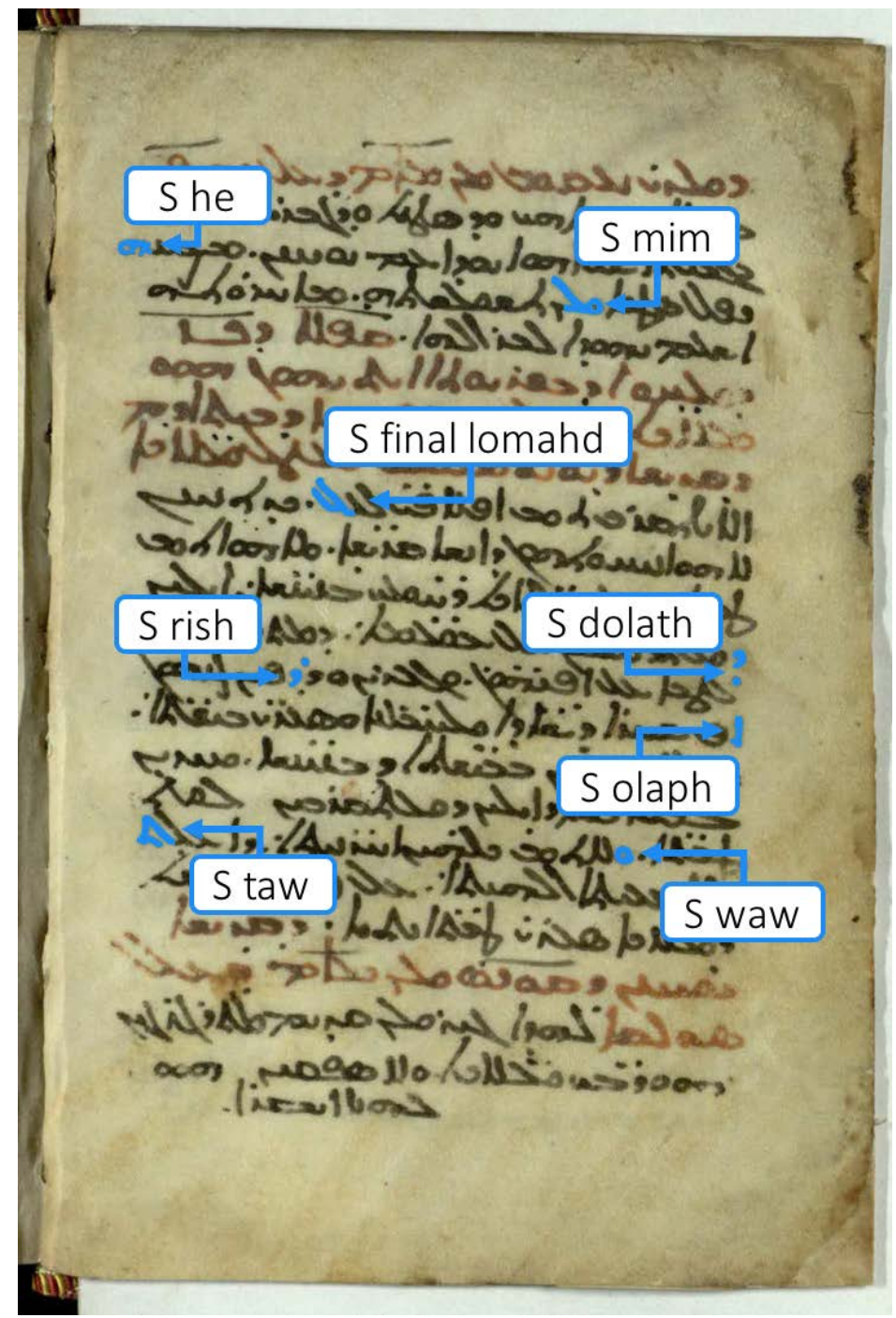

Figure 3. British Library Additional 17,194, f. 20b. Securely dated to 886 CE, this manuscript matches the Standard Model of a Serto manuscript. All of its variable letters appear in the forms text books attribute to Serto and that we are calling S forms. (C) British Library Board: BL. Add. 17,194. 

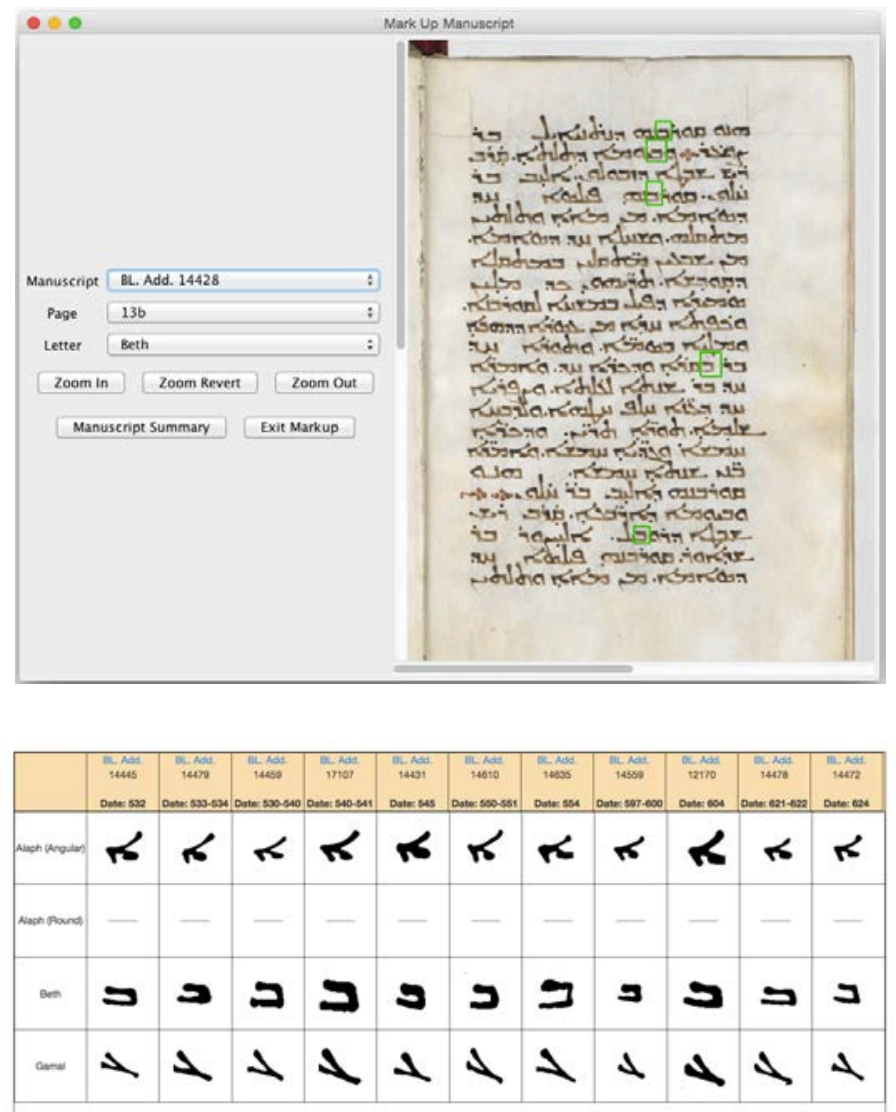

Figure 4. Automated Script Charting of Securely Dated Syriac Manuscripts. To help visualize the development of Syriac script, research assistants used a Java interface that we designed to capture letter data from hundreds of early, securely dated manuscripts (above). A research assistant selected a given letter form from a pull down menu (in this case a beth) and then identified six to ten examples using selection boxes (originally green). The computer extracted the tens of thousands of resulting letter images which were later binarized, proofed, and digitally trimmed. The computer can then automatically generate custom designed script charts (below). (C) British Library Board: BL. Add. 14,428; BL. Add. 12,170; BL. Add. 14,431; BL. Add. 14,445; BL. Add. 14,459; BL. Add. 14,472; BL. Add. 14,478; BL. Add. 14,479; BL. Add. 14,559; BL. Add. 14,610; BL. Add. 14,635; BL. Add. 17,107 . 


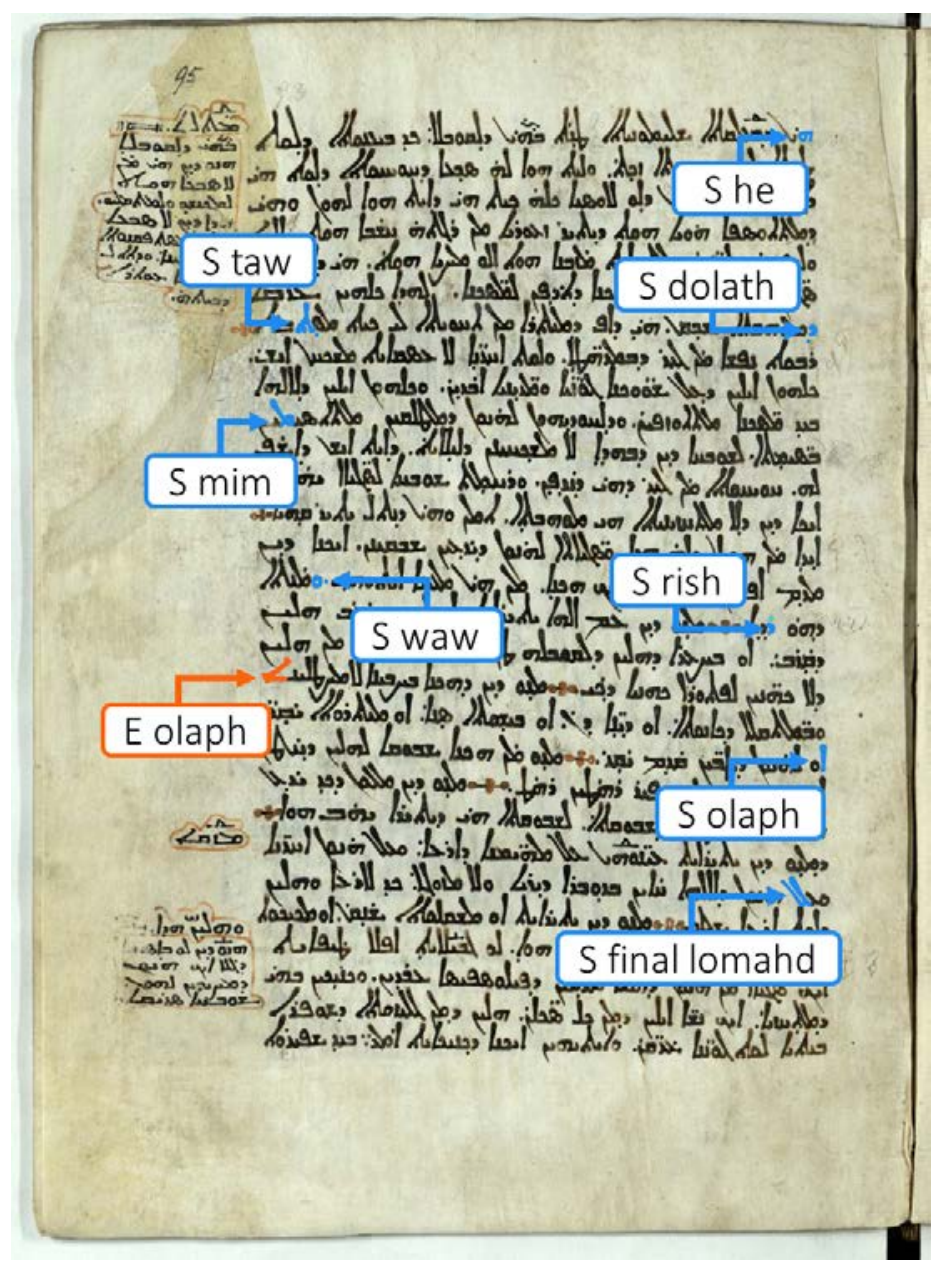

Figure 5. British Library Additional 14,548, f. 95a. Securely dated to $790 \mathrm{CE}$, this manuscript demonstrates the use of both $\mathrm{E}$ and $\mathrm{S}$ forms of olaph in what most text books would define as a Serto script. The scribe most often uses an E olaph toward the end of a line, likely as a means to help justify the text. According to the Standard Model, a document should only have one olaph form, and in this case that form should have been S. But in reality, like many scribes, the scribe of British Library 14,548 used both $\mathrm{S}$ and $\mathrm{E}$ forms of the olaph. (C) British Library Board: BL. Add. 14,548. 


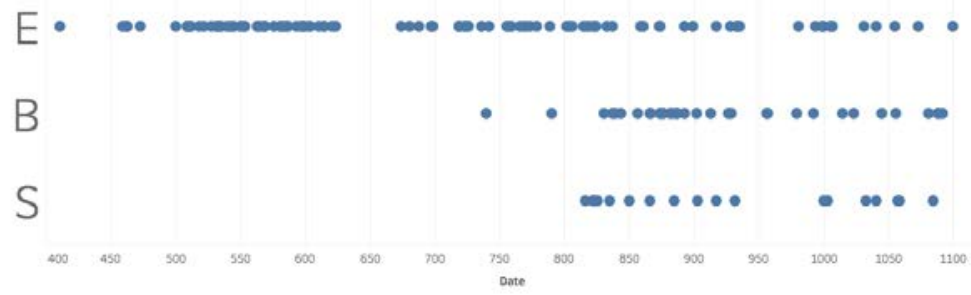

Figure 6. Scatter Plot Indicating E and S forms of Olaphs Among Early, Securely Dated Syriac Manuscripts. Letter data from 175 manuscripts securely dated to before the twelfth century is here plotted as containing just E olaphs (E), just $\mathrm{S}$ olaphs (S), or both forms (B). The resulting scatter plot indicates that a fair number of early Syriac scribes used both $\mathrm{E}$ and $\mathrm{S}$ forms of the olaph. A similar pattern can be observed with most of the other variable letters. 


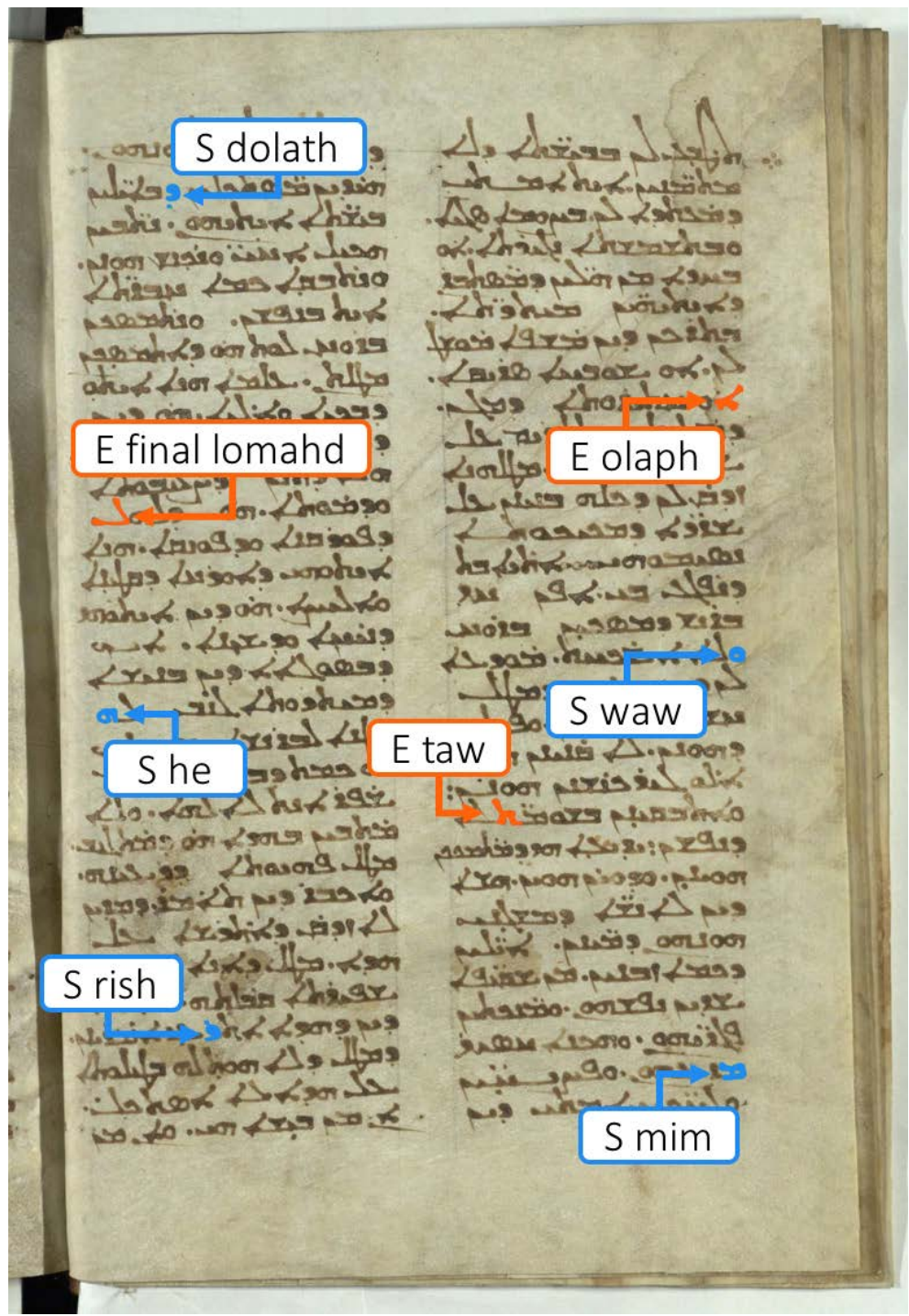

Figure 7. British Library Additional 14,579, f. 10b. Securely dated to 913 CE, this manuscript has a mixture of E letter forms (here olaph, taw, and final lomadh) and S letter forms (here dolath, he, waw, mim, and rish). Such a combination of $\mathrm{E}$ and $\mathrm{S}$ letters is quite common among early Syriac manuscripts. (C) British Library Board: BL. Add. 14,579. 


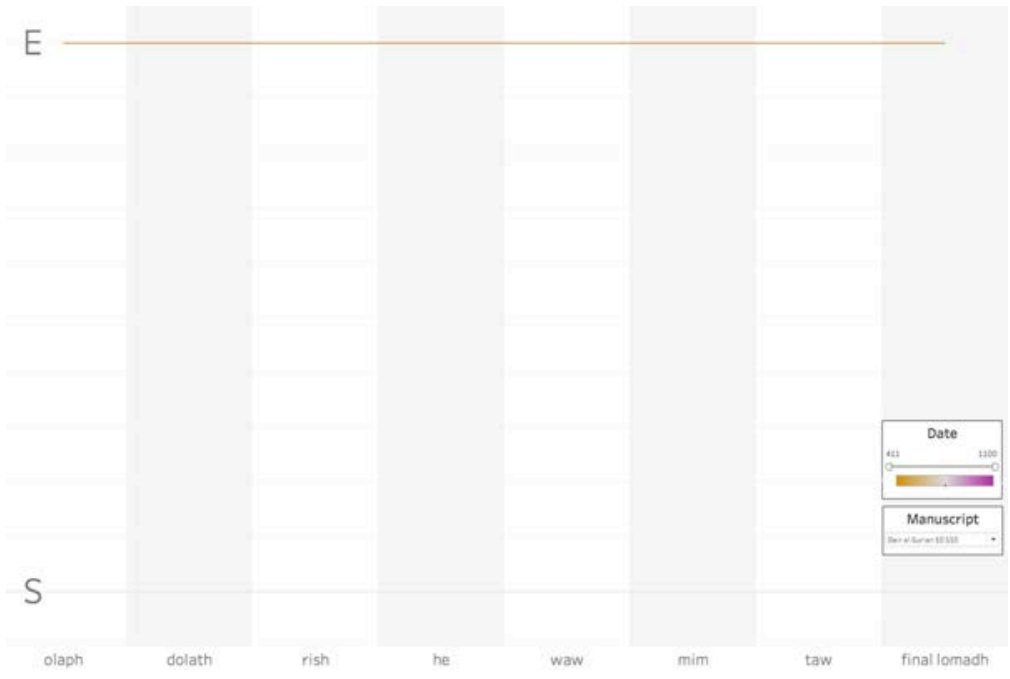

Figure 8. Parallel Coordinates Plot Illustrating the Use of E and S forms in a Single Manuscript. This chart indicates whether a specific manuscript has an $\mathrm{E}$ form of a given letter (top of chart), an S form of a given letter (bottom of chart), or both forms of a given letter (middle of chart). This allows one to quickly detect cases where a manuscript mixes $\mathrm{E}$ and $\mathrm{S}$ forms of a given letter. In this case, the manuscript Deir al-Surian 10 matches the text book definition of Estrangela and only has $\mathrm{E}$ forms of all the variable letters. As a result, the plot is a single horizontal line at the chart's top. The on-line version (https://tinyurl.com/EstrangelaSerto) is interactive allowing the user to specify a given date range or individual manuscripts that they wish to display. 


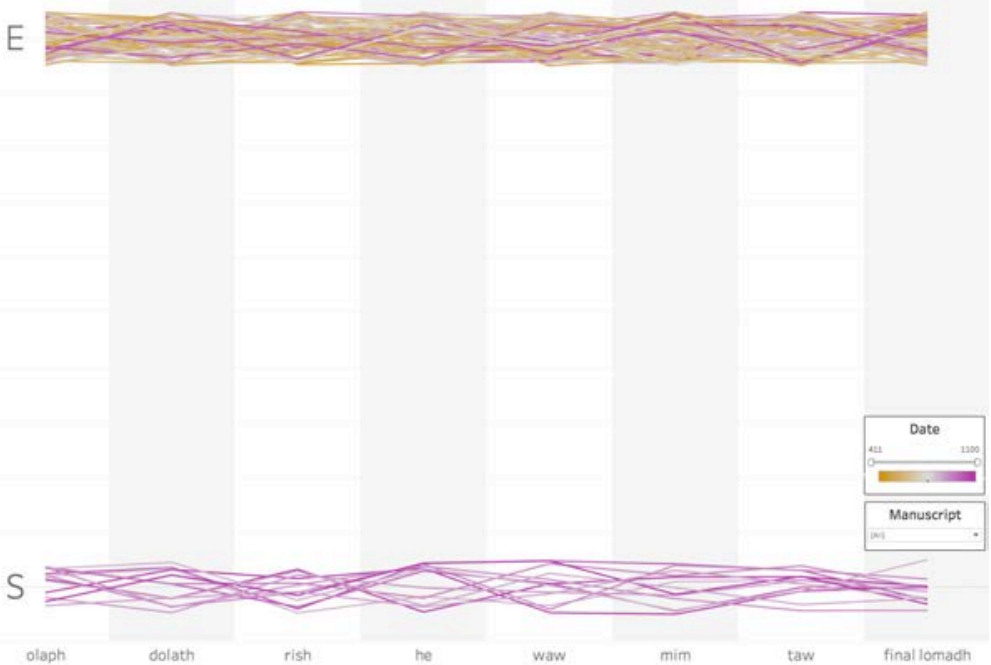

Figure 9. Hypothetical Parallel Coordinates Plot Assuming Early Manuscripts Followed the Standard Model. This is not a chart of actual manuscript data but rather an illustration of what this lay-out of this chart would look like if the Standard Model were correct. In this case all 175 lines would appear either at the top of the chart (for those manuscripts having exclusively $\mathrm{E}$ forms) or at the bottom of the chart (for those manuscripts having exclusively $\mathrm{S}$ forms). 


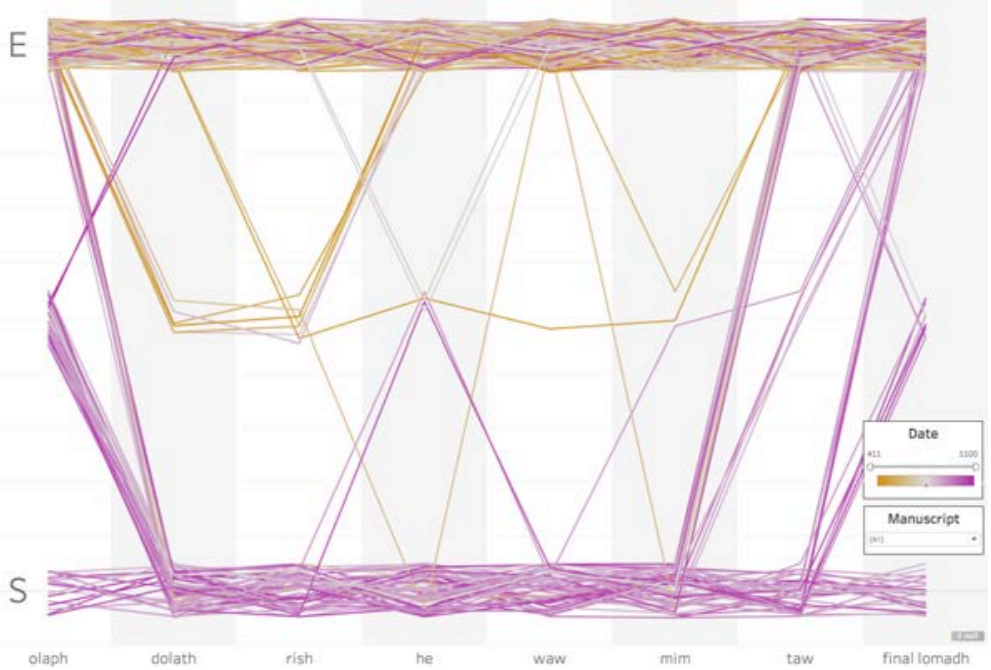

Figure 10. Actual Parallel Coordinates Plot of Early Securely Dated Manuscripts. The chart generated from actual securely dated manuscripts differs substantially from Figure 9. Every time a line crosses from top to bottom or bottom to top it represents a scribe using the $\mathrm{E}$ form of some letters but the $\mathrm{S}$ form of others. 


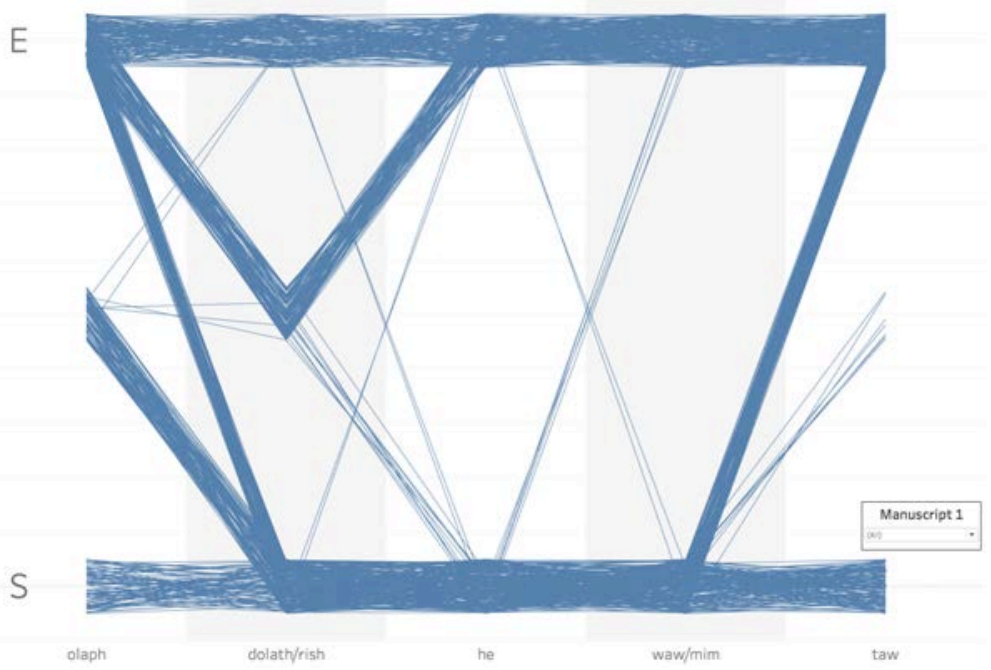

Figure 11. Parallel Coordinates Plot of British Library Manuscripts with an Estimated Composition Date of the Fifth- through Eleventh Century. As with securely dated manuscripts, data from 593 manuscripts that the cataloger William Wright estimated as being written prior to the 1100 s also shows the prevalence of mixed-script manuscripts. Every time a line crosses from top to bottom or bottom to top it represents a scribe using the $\mathrm{E}$ form of some letters but the $\mathrm{S}$ form of others. 


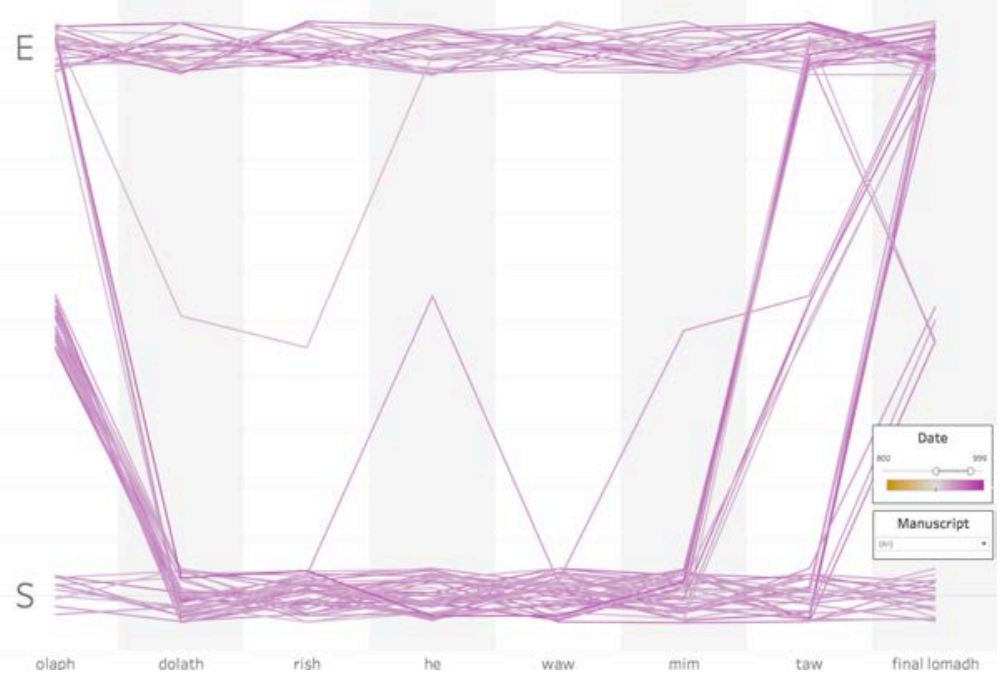

Figure 12. Parallel Coordinates Plot of Manuscripts Securely Dated to the Ninth and Tenth Centuries. As this chart illustrates, Syriac scribes writing in the 800 s and 900 s were particularly prone to use a mixture of $\mathrm{E}$ forms for some letters and $\mathrm{S}$ forms for others. In this case $46 \%$ of the 61 manuscripts securely dated to the ninth and tenth centuries contain a mixture of $\mathrm{E}$ and $\mathrm{S}$ letters. 


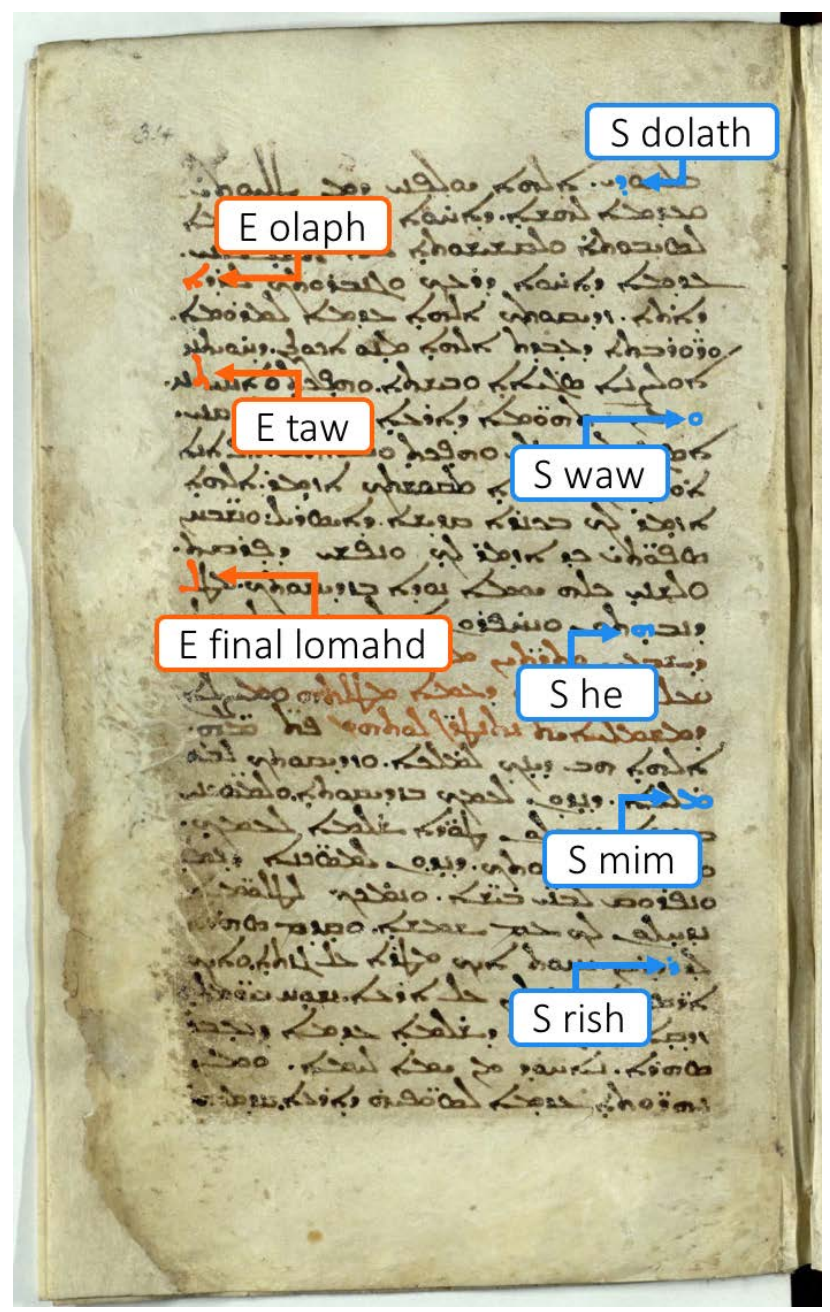

Figure 13. British Library Additional 17,110, f. 34a. Dated to 599/600 CE this manuscript contains the earliest, securely dated appearances of the $S$ form of he and a consistent $S$ form of waw, and mim. It also contains $S$ forms of dolath, and rish. But the scribe still used $\mathrm{E}$ forms of olaph, taw, and final lomadh. A potentially earlier manuscript, Vatican Syriac 137, has the same letter pattern. Unfortunately, the year which appeared in that manuscript's colophon is no longer legible. But, if the earliest catalogers were correct in their reconstruction of the colophon, then Vatican Syriac 137 would have been written in $564 \mathrm{CE}$ and witnesses a slightly earlier appearance of these letter forms. (C) British Library Board: BL. Add. 17,110. 


\begin{tabular}{|c|c|c|c|c|c|c|}
\hline Manuscript & $\begin{array}{l}\text { Letter } \\
\text { Forms }\end{array}$ & Scholar A & Scholar B & Scholar C & Scholar D & Scholar E \\
\hline $\begin{array}{l}\text { BL. Add. } \\
17,126\end{array}$ & All E & Estrangela & Estrangela & Estrangela & Estrangela & Estrangela \\
\hline $\begin{array}{l}\text { BL. Add. } \\
17,182 B\end{array}$ & All E & Estrangela & Estrangela & Estrangela & Estrangela & Estrangela \\
\hline Vat. Syr. 13 & All E & Estrangela & Estrangela & Estrangela & Estrangela & Estrangela \\
\hline $\begin{array}{l}\text { BL. Add. } \\
7157\end{array}$ & All E & Estrangela & Estrangela & Estrangela & Estrangela & Estrangela \\
\hline $\begin{array}{l}\text { BL. Add. } \\
12,160\end{array}$ & All E & Estrangela & Estrangela & Estrangela & Estrangela & Estrangela \\
\hline $\begin{array}{l}\text { BL. Add. } \\
14,428\end{array}$ & All E & Estrangela & Estrangela & Estrangela & Estrangela & Estrangela \\
\hline $\begin{array}{l}\text { BL. Add. } \\
14,448\end{array}$ & All E & Estrangela & Estrangela & Estrangela & Estrangela & Estrangela \\
\hline $\begin{array}{l}\text { BL. Add. } \\
14,623\end{array}$ & All S & $\begin{array}{l}\text { Serto } \\
\text { Serto }\end{array}$ & $\begin{array}{l}\text { Serto } \\
\text { Serto }\end{array}$ & $\begin{array}{l}\text { Serto } \\
\text { Medial }\end{array}$ & $\begin{array}{l}\text { Serto } \\
\text { Medial }\end{array}$ & $\begin{array}{l}\text { Serto } \\
\text { Serto }\end{array}$ \\
\hline $\begin{array}{l}\text { BL. Add. } \\
12,153\end{array}$ & All S & $\begin{array}{l}\text { Serto } \\
\text { Serto }\end{array}$ & $\begin{array}{l}\text { Serto } \\
\text { Serto }\end{array}$ & $\begin{array}{l}\text { Estrangela } \\
\text { Medial }\end{array}$ & $\begin{array}{l}\text { Serto } \\
\text { Medial }\end{array}$ & $\begin{array}{l}\text { Serto } \\
\text { Medial }\end{array}$ \\
\hline $\begin{array}{l}\text { BL. Add. } \\
14,580\end{array}$ & All S & $\begin{array}{l}\text { Serto } \\
\text { Serto }\end{array}$ & $\begin{array}{l}\text { Serto } \\
\text { Serto }\end{array}$ & $\begin{array}{l}\text { Serto } \\
\text { Serto }\end{array}$ & $\begin{array}{l}\text { Serto } \\
\text { Medial }\end{array}$ & $\begin{array}{l}\text { Serto } \\
\text { Serto }\end{array}$ \\
\hline $\begin{array}{l}\text { BL. Add. } \\
14,582\end{array}$ & All S & $\begin{array}{l}\text { Serto } \\
\text { Serto }\end{array}$ & $\begin{array}{l}\text { Serto } \\
\text { Serto }\end{array}$ & $\begin{array}{l}\text { Serto } \\
\text { Serto }\end{array}$ & $\begin{array}{l}\text { Serto } \\
\text { Medial }\end{array}$ & $\begin{array}{l}\text { Serto } \\
\text { Serto }\end{array}$ \\
\hline $\begin{array}{l}\text { BL. Add. } \\
14,651\end{array}$ & All S & $\begin{array}{l}\text { Serto } \\
\text { Serto }\end{array}$ & $\begin{array}{l}\text { Serto } \\
\text { Serto }\end{array}$ & $\begin{array}{l}\text { Serto } \\
\text { Serto }\end{array}$ & $\begin{array}{l}\text { Serto } \\
\text { Medial }\end{array}$ & $\begin{array}{l}\text { Serto } \\
\text { Serto }\end{array}$ \\
\hline
\end{tabular}

Figure 14. Scholars' Classification of Sample Manuscripts with All E or All S Letters. Even among those manuscripts that matched the text book definition of Estrangela and Serto (that is, they had all E or all S letters), there still was disagreement among surveyed scholars over how to classify them. The top of each cell lists the scholar's choice given only the categories of Estrangela and Serto. The bottom of each cell lists the scholar's choice when also given the option of a third category, Medial. Minority opinions appear in bold. 


\begin{tabular}{|c|c|c|c|c|c|c|}
\hline cript & $\begin{array}{l}\text { Letter } \\
\text { Forms }\end{array}$ & $\mathbf{A}$ & B & C & D & \\
\hline Vat. Syr. 14 & $\begin{array}{l}\text { Mixed } \\
\text { E \& S }\end{array}$ & $\begin{array}{l}\text { Estrangela } \\
\text { Medial }\end{array}$ & $\begin{array}{l}\text { Serto } \\
\text { Medial }\end{array}$ & $\begin{array}{l}\text { Estrangela } \\
\text { Estrangela }\end{array}$ & $\begin{array}{l}\text { Estrangela } \\
\text { Medial }\end{array}$ & $\begin{array}{l}\text { Estrangela } \\
\text { Medial }\end{array}$ \\
\hline Vat. Syr. 137 & $\begin{array}{l}\text { Mixed } \\
\text { E \& S }\end{array}$ & $\begin{array}{l}\text { Estrangela } \\
\text { Medial }\end{array}$ & $\begin{array}{l}\text { Estrangela } \\
\text { Medial }\end{array}$ & $\begin{array}{l}\text { Estrangela } \\
\text { Estrangela }\end{array}$ & $\begin{array}{l}\text { Estrangela } \\
\text { Estrangela }\end{array}$ & $\begin{array}{l}\text { Estrangela } \\
\text { Medial }\end{array}$ \\
\hline $\begin{array}{l}\text { 3L. Add. } \\
4,679\end{array}$ & $\begin{array}{l}\text { Mixed } \\
\text { E \& S }\end{array}$ & $\begin{array}{l}\text { Serto } \\
\text { Serto }\end{array}$ & $\begin{array}{l}\text { Serto } \\
\text { Serto }\end{array}$ & $\begin{array}{l}\text { Estrangela } \\
\text { Medial }\end{array}$ & $\begin{array}{l}\text { Serto } \\
\text { Medial }\end{array}$ & $\begin{array}{l}\text { Serto } \\
\text { Serto }\end{array}$ \\
\hline $\begin{array}{l}\text { BL. Add. } \\
\text { 12,139 }\end{array}$ & $\begin{array}{l}\text { Mixed } \\
\text { E \& S }\end{array}$ & $\begin{array}{l}\text { Estrangela } \\
\text { Medial }\end{array}$ & $\begin{array}{l}\text { Estrangela } \\
\text { Estrangela }\end{array}$ & $\begin{array}{l}\text { Estrangela } \\
\text { Estrangela }\end{array}$ & $\begin{array}{l}\text { Estrangela } \\
\text { Medial }\end{array}$ & $\begin{array}{l}\text { Estrangela } \\
\text { Estrangela }\end{array}$ \\
\hline $\begin{array}{l}\text { BL. Add. } \\
17,110\end{array}$ & $\begin{array}{l}\text { Mixed } \\
\text { E \& S }\end{array}$ & $\begin{array}{l}\text { Estrangela } \\
\text { Medial }\end{array}$ & $\begin{array}{l}\text { Estrangela } \\
\text { Estrangela }\end{array}$ & $\begin{array}{l}\text { Estrangela } \\
\text { Estrangela }\end{array}$ & $\begin{array}{l}\text { Estrangela } \\
\text { Medial }\end{array}$ & $\begin{array}{l}\text { Estrangela } \\
\text { Estrangela }\end{array}$ \\
\hline $\begin{array}{l}\text { BL. Add. } \\
17,174\end{array}$ & $\begin{array}{l}\text { Mixed } \\
\text { E \& S }\end{array}$ & $\begin{array}{l}\text { Serto } \\
\text { Serto }\end{array}$ & & $\begin{array}{l}\text { Serto } \\
\text { Medial }\end{array}$ & & $\begin{array}{l}\text { Serto } \\
\text { Medial }\end{array}$ \\
\hline $\begin{array}{l}\text { Dam. Patr. } \\
12 / 13\end{array}$ & $\begin{array}{l}\text { Mixed } \\
\text { E\& S }\end{array}$ & $\begin{array}{l}\text { Estrangela } \\
\text { Medial }\end{array}$ & $\begin{array}{l}\text { Estrangela } \\
\text { Medial }\end{array}$ & $\begin{array}{l}\text { Estrangela } \\
\text { Estrangela }\end{array}$ & $\begin{array}{l}\text { Estrangela } \\
\text { Medial }\end{array}$ & $\begin{array}{l}\text { Estrangela } \\
\text { Estrangela }\end{array}$ \\
\hline $\begin{array}{l}\text { BL. Add. } \\
14,686\end{array}$ & $\begin{array}{l}\text { Mixed } \\
\text { E \& S }\end{array}$ & $\begin{array}{l}\text { Estrangela } \\
\text { Medial }\end{array}$ & $\begin{array}{l}\text { Estrangela } \\
\text { Medial }\end{array}$ & $\begin{array}{l}\text { Estrangela } \\
\text { Estrangela }\end{array}$ & $\begin{array}{l}\text { Estrangela } \\
\text { Medial }\end{array}$ & $\begin{array}{l}\text { Estrangela } \\
\text { Estrangela }\end{array}$ \\
\hline $\begin{array}{l}\text { BL. Add. } \\
17,125\end{array}$ & $\begin{array}{l}\text { Mixed } \\
\text { E \& S }\end{array}$ & $\begin{array}{l}\text { Serto } \\
\text { Serto }\end{array}$ & $\begin{array}{l}\text { Serto } \\
\text { Serto }\end{array}$ & $\begin{array}{l}\text { Estrangela } \\
\text { Medial }\end{array}$ & $\begin{array}{l}\text { Serto } \\
\text { Medial }\end{array}$ & $\begin{array}{l}\text { Serto } \\
\text { Medial }\end{array}$ \\
\hline $\begin{array}{l}\text { BL. Add. } \\
17,256\end{array}$ & $\begin{array}{l}\text { Mixed } \\
\text { E \& S }\end{array}$ & $\begin{array}{l}\text { Estrangela } \\
\text { Medial }\end{array}$ & $\begin{array}{l}\text { Estrangela } \\
\text { Medial }\end{array}$ & $\begin{array}{l}\text { Estrangela } \\
\text { Estrangela }\end{array}$ & $\begin{array}{l}\text { Estrangela } \\
\text { Medial }\end{array}$ & $\begin{array}{l}\text { Estrangela } \\
\text { Estrangela }\end{array}$ \\
\hline $\begin{array}{l}\text { BL. Add. } \\
17,165\end{array}$ & $\begin{array}{l}\text { Mixed } \\
\text { E \& S }\end{array}$ & $\begin{array}{l}\text { Estrangela } \\
\text { Medial }\end{array}$ & $\begin{array}{l}\text { Estrangela } \\
\text { Medial }\end{array}$ & $\begin{array}{l}\text { Estrangela } \\
\text { Estrangela }\end{array}$ & $\begin{array}{l}\text { Estrangela } \\
\text { Medial }\end{array}$ & $\begin{array}{l}\text { Estrangela } \\
\text { Estrangela }\end{array}$ \\
\hline Vat. Syr. 152 & $\begin{array}{l}\text { Mixed } \\
\text { E\& S }\end{array}$ & $\begin{array}{l}\text { Estrangela } \\
\text { Medial }\end{array}$ & $\begin{array}{l}\text { Estrangela } \\
\text { Estrangela }\end{array}$ & $\begin{array}{l}\text { Estrangela } \\
\text { Estrangela }\end{array}$ & $\begin{array}{l}\text { Estrangela } \\
\text { Medial }\end{array}$ & $\begin{array}{l}\text { Estrangela } \\
\text { Estrangela }\end{array}$ \\
\hline $\begin{array}{l}\text { BL. Add. } \\
14,471\end{array}$ & $\begin{array}{l}\text { Mixed } \\
\text { E \& S }\end{array}$ & $\begin{array}{l}\text { Estrangela } \\
\text { Medial }\end{array}$ & $\begin{array}{l}\text { Estrangela } \\
\text { Estrangela }\end{array}$ & $\begin{array}{l}\text { Estrangela } \\
\text { Medial }\end{array}$ & $\begin{array}{l}\text { Estrangela } \\
\text { Medial }\end{array}$ & $\begin{array}{l}\text { Estrangela } \\
\text { Estrangela }\end{array}$ \\
\hline BL. Or. 8731 & $\begin{array}{l}\text { Mixed } \\
\text { E \& S }\end{array}$ & $\begin{array}{l}\text { Estrangela } \\
\text { Medial }\end{array}$ & $\begin{array}{l}\text { Serto } \\
\text { Serto }\end{array}$ & $\begin{array}{l}\text { Estrangela } \\
\text { Medial }\end{array}$ & $\begin{array}{l}\text { Estrangela } \\
\text { Medial }\end{array}$ & $\begin{array}{l}\text { Estrangela } \\
\text { Medial }\end{array}$ \\
\hline Vat. Syr. 467 & $\begin{array}{l}\text { Mixed } \\
\text { E \& S }\end{array}$ & $\begin{array}{l}\text { Estrangela } \\
\text { Medial }\end{array}$ & $\begin{array}{l}\text { Serto } \\
\text { Medial }\end{array}$ & $\begin{array}{l}\text { Estrangela } \\
\text { Estrangela }\end{array}$ & $\begin{array}{l}\text { Estrangela } \\
\text { Medial }\end{array}$ & $\begin{array}{l}\text { Estrangela } \\
\text { Medial }\end{array}$ \\
\hline $\begin{array}{l}\text { BL. Add. } \\
14,579\end{array}$ & $\begin{array}{l}\text { Mixed } \\
\text { E \& S }\end{array}$ & $\begin{array}{l}\text { Estrangela } \\
\text { Medial }\end{array}$ & $\begin{array}{l}\text { Estrangela } \\
\text { Medial }\end{array}$ & $\begin{array}{l}\text { Estrangela } \\
\text { Estrangela }\end{array}$ & $\begin{array}{l}\text { Estrangela } \\
\text { Medial }\end{array}$ & $\begin{array}{l}\text { Estrangela } \\
\text { Estrangela }\end{array}$ \\
\hline $\begin{array}{l}\text { BL. Add. } \\
14,515\end{array}$ & $\begin{array}{l}\text { Mixed } \\
\text { E \& S }\end{array}$ & $\begin{array}{l}\text { Estrangela } \\
\text { Medial }\end{array}$ & $\begin{array}{l}\text { Estrangela } \\
\text { Medial }\end{array}$ & $\begin{array}{l}\text { Estrangela } \\
\text { Medial }\end{array}$ & $\begin{array}{l}\text { Estrangela } \\
\text { Medial }\end{array}$ & $\begin{array}{l}\text { Estrangela } \\
\text { Medial }\end{array}$ \\
\hline $\begin{array}{l}\text { BL. Add. } \\
14,650\end{array}$ & $\begin{array}{l}\text { Mixed } \\
\text { E \& S }\end{array}$ & $\begin{array}{l}\text { Serto } \\
\text { Serto }\end{array}$ & $\begin{array}{l}\text { Serto } \\
\text { Serto }\end{array}$ & $\begin{array}{l}\text { Serto } \\
\text { Medial }\end{array}$ & $\begin{array}{l}\text { Serto } \\
\text { Medial }\end{array}$ & $\begin{array}{l}\text { Serto } \\
\text { Medial }\end{array}$ \\
\hline $\begin{array}{l}\text { BL. Add. } \\
12,152\end{array}$ & $\begin{array}{l}\text { Mixed } \\
\text { E\& S }\end{array}$ & $\begin{array}{l}\text { Estrangela } \\
\text { Medial }\end{array}$ & $\begin{array}{l}\text { Serto } \\
\text { Medial }\end{array}$ & $\begin{array}{l}\text { Estrangela } \\
\text { Medial }\end{array}$ & $\begin{array}{l}\text { Estrangela } \\
\text { Medial }\end{array}$ & $\begin{array}{l}\text { Estrangela } \\
\text { Estrangela }\end{array}$ \\
\hline
\end{tabular}

Figure 15. Scholars' Classification of Manuscripts Containing Both E and S Letters. Surveyed scholars substantially disagreed on how to classify manuscripts 
that either had both $\mathrm{E}$ and $\mathrm{S}$ forms of a single letter or $\mathrm{E}$ forms of some letters and $\mathrm{S}$ forms of others. There was scholarly consensus on how to classify only one of the nineteen mixed-script manuscripts in the survey. The top of each cell lists the scholar's choice given only the categories of Estrangela and Serto. The bottom of each cell lists the scholar's choice when also given the option of a third category, Medial. 